\title{
THE AFTERLIFE OF GENDER: Sovereignty, Intimacy, and Muslim Funerals of Transgender People in Turkey
}

\author{
ASLI ZENGIN \\ Brown University \\ (iD https:/ / orcid.org/0000-0002-5450-7953
}

It was a bright, sunny day in May 2010 in Istanbul. At around noon, I reached the mosque for the funeral of Sibel, a trans woman sex worker. A big crowd of trans women had gathered in the narrow street surrounding the mosque. Some trans women followed Islamic tradition and came to the funeral with headscarves, while others were bareheaded. ${ }^{1}$ Sibel, a close friend to many trans women in Istanbul LGBTT, a trans-majority LGBTQ organization, had suffered a cerebral hemorrhage a few days earlier, while soliciting sex work at night. After her emergency hospitalization, trans people from Istanbul LGBTT took turns visiting and caring for her. Like most trans women in Turkey, Sibel had been abandoned by her blood family. So her trans friends informed Sibel's blood family about her situation, but the family paid little attention to Sibel, who had lost consciousness after the hemorrhage, as she remained in the hospital. A few days after being admitted, Sibel passed away.

Sibel had identified and lived her life as a woman. Yet in the eyes of the Turkish state she was a man, and hence held a blue ID card, the color of state-issued ID cards for male citizens. ${ }^{2}$ Had she completed her official gender transition, an arduous medico-legal process that takes about two years, ${ }^{3}$ she could have been holding a pink ID card and been officially recognized as female at the moment of her death. Sibel had 
had breast reconstructive surgery but still had a penis, a bodily configuration that transgressed the strict gender binary institutional categories of female and male.

Sibel's body invoked a chaos of illegibility at her funeral ceremony and burial ritual, opening gender and sexual difference to debates and negotiations by a variety of social actors. Religious authorities, particularly imams, as well as members of Sibel's blood family and state medico-legal actors from the Department of Funeral and Cemetery Services, started to discuss the deceased's "real" sex and gender. Sibel's sex/gender-transgressive body became a source of multiple interpretations and inscriptions of categories revolving around not only female/male and woman/ man but also kinship, religion, and citizenship. Sibel's friends from the LGBTQ activist community also played a part in these negotiations, challenging other actors' claims and advocating for Sibel to be mourned as female/woman and as their kin.

The afterlife of a normative death usually manifests a collaborative work of multiple sovereign registers to bid farewell to the deceased. The blood family, together with the state, guides the formation of an intimate alliance between legal frameworks, religious authorities, friends, and community to ensure the proper mourning and burial of the person who has died. This intimate alliance pivots on shared forms of sovereignty that the state, the family, and, in the case of Turkey, Islam secure over the body of the deceased - sovereignties related to and embedded within each other.

The afterlife of a transgressive death, ${ }^{4}$ however, ruptures these alliances and offers a window into the contours and limits of different sovereign registers and intimate claims over the body. The ruptures and sutures may be ethnic, religious, sectarian, and economic in addition to gendered or sexed. Sunni Muslim transgender deaths, the main focus of this article, provide just one example for such transgressive deaths. The afterlives of transgender deaths demonstrate how sex, gender, and sexual difference, as a social field of constant and emergent contestation, mark the gendered and sexual limits of belonging in sovereign regimes of Islam, family, kinship, and citizenship, and in practices of mourning and grief. A mortuary ethnography of these funerals and burial rituals in Turkey evinces the shifting alliances of a framework formed by Islamic notions of embodiment, familial order, gender and sexuality regimes, and legal regulations around death.

Here, I find it useful to approach sovereignty as "a tentative and emergent form of authority always grounded in violence that is performed and designed to generate loyalty, fear, and legitimacy" (Hansen and Stepputat 2006, 297). Seen from this perspective, the body, both dead and alive, demands attention as a site and object of sovereign power. At transgender funerals such as Sibel's, we see the multiple 
and segmented work of sovereignty enacted through the body. Turning the body into a site of constant and emergent contestation, sovereignty_-both statist and nonstatist, official and popular - becomes multiple, opening sexual/gender difference to debates and negotiations by a variety of social actors, including medico-legal authorities, imams, family members, friends, and LGBTQ activists in Istanbul. The work of sovereignty through the body establishes intimate legal alliances between families, religious authorities, and the state, alliances that might invalidate the intimate claims that LGBTQ people make over each other in life and in death. As I will demonstrate, the hetero-reproductive blood family, through its legally and religiously secured privileged place and rights to intimacy and sovereignty over the body, can further kill the deceased by abandoning them at their death and funerals.

This framework proves useful for examining how violence and abandonment ground statist and nonstatist forms of sovereignties (e.g., community and queer family making) through the rights and claims to the body. Yet it has also its limits - it does not account for the domain of intimacy that conditions the formation of certain sovereignties through the work of love, affect, and care. The emerging critical work on indigenous and popular forms of sovereignty is key to my thinking of sovereignty in relation to intimacy. This literature stresses substantial and contextual variations in the formation of sovereignty, and approaches sovereignty as fragmented, emergent, interdependent, uneven, nested, and polymorphous (Hansen and Stepputat 2006; Comaroff and Comaroff 2009; Navaro-Yashin 2012; Simpson 2014; Bishara 2017). Amahl Bishara (2017, 350), for instance, draws our attention to those forms of popular sovereignties that are "provisional, not resting on enforceable law or acknowledged rights . . . but rather on either insistent confrontation or quiet acts of caring for community in the face of abandonment." These communally practiced forms of sovereignty do not necessarily restructure existing state power, but instead produce new collectivities, contest the legitimacy of state authorities, and offer different formulations for the operation of power. In Caroline Humphrey's $(2004,420)$ words, these "localized forms of sovereignties" are usually "nested within higher sovereignties," yet they still "retain a domain within which control over life and death is operational."

Expanding on these discussions, I suggest that at the thresholds of dominant regimes, sovereignty manifests itself not only in statist and official forms through legal regimes of family and citizenship, social scripts of religion and ethnicity, and dominant frameworks of gender and sexuality but also in nonstatist and popular forms through an intertwined network of care, labor, affect, and love. As the afterlife of Sibel's sex/gender-transgressive body will demonstrate, if violence is one 
essential dimension of sovereignty then intimacy is another one, and in some cases these mutually shape and constitute each other (see Zengin 2016b).

Though my ethnography draws mainly from sexual/gender transgression and trans lives and deaths in Turkey, my theoretical contribution expands beyond transness and gender nonconformity to engage with novel ways of thinking relationships between sovereignty, intimacy, and death in the margins of the social. Death and its afterlife at these social thresholds make for compelling sites to examine distinct yet overlapping formations of sovereignty and intimacy, as well as the intricate, coconstitutive, and prolific relationship between them. To that end, this article traces some of the analytical and theoretical paths that we find ourselves on when we start thinking sovereignty as intimacy and intimacy as sovereignty.

Before continuing, a few words on methodology: this essay results from ethnographic work conducted with transgender people during different periods between 2009 and 2012 in Istanbul, Turkey. My research took place across several research sites, ranging from LGBTQ organizations to transgender people's homes and neighborhoods, as well as the cafés, bars, and streets they frequented. I attended conferences, parties, funerals, meetings, and political campaigns for gender rights and against hate crimes. I also conducted interviews with transgender people, lawyers, consultants, doctors, and social and NGO workers; gathered legal codes and documents on gender reassignment surgeries, the issuance of new ID cards, and transgender killings; and collected official and historical documents, newspapers, blog articles, and novels about sex/gender-transgressive people in Turkey.

\section{SOVEREIGN INTIMACIES: Family, Kin, Friends, and LGBTQ Community}

Achille Mbembe's (2003, 39) concept of necropolitics famously theorizes "contemporary forms of subjugation of life to the power of death." Necropolitics is captious: it locates traditional forms of sovereignty (e.g., state or religious authority) alongside a more comprehensive politics of death, as well as the contemporary production of "death worlds" (Mbembe 2003, 40). Sovereignty, in this understanding, operates as having a capacity to make death central to the life of the oppressed. In this "symbiotic copresence of life and death" (Haritaworn, Kuntsman and Posocco 2014, 2), there is a differential invitation into life for different groups of people: while some take pleasure in inhabiting norms, others are abjected and marked for slow or immediate death. For racialized queers and transgender people, for example, livability and killability usually operate as two sides of the same coin by pro- 
viding publicity and visibility to some, and disposability and erasure to others (see Edelman 2014; Shakhsari 2014).

Necropolitics is crucial to understanding the relationship between sovereignty and death, including at moments when decisions are made to end a life or prolong it under conditions of suffering and harm, when life is a "slow death" (Berlant 2007). Necropolitics, however, reaches a theoretical limit when we move our attention to the afterlife of the dead and the many forms that this afterlife takes, including the political production and destruction of the afterlife itself. My thinking on sovereignty offers a shift from the capacity to "kill or let live" to a different yet complementary form of violence that draws from the domain of death, the realm of the postmortem, and relations with the corpse and the afterlife.

In an article about Ekin Wan, a PKK (Kurdistan Worker's Party) guerrilla woman whose dead and tortured body Turkish soldiers exhibited naked in the streets of Kurdistan in 2015, Nazan Üstündağ (2015) draws our attention to the sovereign's warfare over the dead of the oppressed. Using the death of the other, states attempt to punish communities beyond mortality and inscribe themselves on communal relations of intimacy. Üstündağ notes that states ruin and poison the relations with the dead and, in that way, reshape relations with the hereafter, the divine, and the world of faith. In the 1990s, the Turkish state adopted a widespread war strategy of disappearing Kurdish people, later dumping the dead guerrilla bodies in garbage-processing sites and landfills, preventing the community from practicing their burial and funeral rituals. Since 2015, with the heightened conflict between Kurdish guerrillas and the Turkish state and intensified siege conditions in several Kurdish towns, a similar tactic of warfare has targeted the dead bodies of Kurds. Death and the afterlife (its customs, burial practices, funeral rituals, relations and symbols of mourning, and so on) have become sites of state warfare against Kurdish resistance. For instance, in 2015, Cemile, a ten-year-old girl from the Kurdish city of Cizre, was shot to death by the Turkish military while playing with her friends in front of her house. After being denied a proper burial by the state, her family had to put her body in a deep freezer to prevent it from rotting (Kamer 2015). The same year, a fifty-five-year-old Kurdish woman, Taybet Inan, was shot to death in the streets of Silopi while returning home from visiting her neighbor during a state-imposed curfew. State security forces prevented Inan's family members from collecting her body from the street, where it remained for seven days (Söylemez 2016), publicly demonstrating the state's power to violate and defile individual and family rights to socially hegemonic death rituals, in this case Muslim burial precepts. 
A number of scholars address this particular form of violence as necropolitical violence or necroviolence, which mainly concerns corporeal mistreatment of the deceased through burial and funeral practices, graves and cemeteries, and acts of mourning and commemoration (see De León 2015; Bargu 2016). Necroviolence intensifies at times of war when death is no longer a threshold but rather a continuation or the beginning of terror. In his dissertation, Hişyar Özsoy (2010) notes that biological killing does not satisfy the nation-state when it comes to people who rebel against its demands. Instead, the nation-state, as the sovereign, prevents the bodies of the dead from gaining significant meaning and a social value. In this way, as Özsoy goes on to argue, the sovereign kills the people in a symbolic as well as political register, and endeavors to separate the dead from the life of a community. When states occupy not only the domain of life but also that of death and the afterlife, they intervene directly into the intimate life of the community and its ability to socially and politically reproduce itself (Zengin 2015).

This particular notion of necroviolence, however, relies on an understanding that places the state and the community in opposition to one another. My research shows that this is not always the case. In the afterlife of a sex/gender-transgressive death and/or a sex worker's passing, the blood family may also become a chief necropolitical actor in an intimate alliance with the state, an alliance that hinges on shared forms of sovereignty on the body of the deceased. The family partakes in sovereignty through those rights to the body that are secured by the state and by Islamic precepts. To understand the alliance between blood families and the state, we must first unpack state and Islamic regulations behind death rituals and practices of mourning in Turkey, both of which define the blood family as the primary holder of obligations for and rights to the deceased. This intimate alliance and the embeddedness of each sovereign register - the state, the family, and Islam — within the others proves crucial to understanding the afterlives of gender.

\section{LAWFUL DEATH: The State and the Blood Family}

The operative functions of modern state power rely on the simultaneous workings of sovereignty and governmentality, each acting as a condition of the other (Dean 2001). People face the widespread embeddedness of sovereign violence in every mundane detail. Through its fruitful capacity of diffusion, expansion, and regulation, governmentality organizes the investments of sovereign power in its management of populations. Within this domain, law has a privileged role and represents the most fundamental characteristic of sovereign power. As John Comaroff 
and Jean Comaroff $(2009,39)$ argue, states build "an architecture of legalities" in order to transform their power into sovereignty.

When it comes to the realm of death, law works in collaboration with medicine to place death at the service of biopolitical life. For example, medical expertise decides when death occurs and life stops, but law relies on and authorizes this medical decision to facilitate rights on the deceased. Those living members of the legally recognized family gain intimate access to the deceased body through legislation concerning inheritance, burial, and funeral, access that consolidates familial sovereignty over the deceased body. Blood ties are crucial in giving value and definition to the dominant understanding of the family in Turkey, and they are inscribed in social, legal, and religious frameworks. One notable example is the legal regulation of IVF treatment, which strictly prohibits egg, sperm, and embryo donation and surrogacy. It allows only married couples to use their own eggs and sperm. A similar emphasis on blood ties is present in the particular realm of death, allocating a hierarchy of intimate rights to the deceased's lineal kinship members based on their ranking in the family organization: first, the deceased's legal spouse and descendants, second, the deceased's parents and their descendants (i.e., siblings), and third, the deceased's grandparents and their descendants (i.e., uncles, aunts, their children, and so on). In the presence of a will, other designated inheritors follow this bloodline. This ranking concerns itself primarily with the order of shares in the material afterworld of the deceased, that is, the distribution of their inheritance. Even if the deceased wrote a will and denied inheritance to the abovementioned blood family members, and even if the deceased bequeathed all their property to someone outside the bloodline, such as a friend or a lover, the state would still guarantee the blood family members a reserved portion of the succession. That is, the state secures the rights of blood family members to material wealth by designating and legislating them as compulsory heirs of the deceased.

Another set of death rights concern claims over the body of the deceased, including choice of burial practice, selection of burial plot, whether or not to have an autopsy, and organ donation. Blood families and spouses have de facto sovereignty over these decisions, unless a will exists that specifies particular death rights and practices. Yet even in the presence of a will, blood families and/or spouses are allowed to contest the decisions of the diseased. Under these conditions, judges must interpret the situation according to existing "customs and traditions" (Özel 2002, 60; author's translation), and judges decide who has rights to the deceased body, or more precisely, who has intimate sovereignty over this particular death. 
But what are the available social scripts and practices for such interpretations? What kind of customs and traditions make consensus possible and allow for the legal designation of the intimate sovereign over the dead body? What are the continuities and ruptures between legal practices and social and cultural scripts concerning the afterlife of a death? To approach these questions, we must move beyond theories of sovereignty that are grounded securely and singularly within the arena of law.

\section{THE DIVINE SOVEREIGN: Allah, Islam, and the Deceased Body}

In Turkey's social and cultural life, Sunni Islam, the hegemonic religious doctrine, often authorizes sovereign claims on sexed/gendered embodiment. The mainstream interpretation of Islam commands that people's bodies - both body surfaces and internal organs _ come from and belong to Allah. The body is Allah's emanet (entrust) to humans; Allah entrusts the body to humans and hence an individual is responsible for taking good care of their body until they return it to Allah. It is therefore not surprising that Sunni Islam requires a meticulous set of body-related rituals at death. A significant dimension of this religious bodywork includes keeping the body clean by washing away things that are considered polluting, such as blood, urine, feces, and semen. Ritual washing is essential to returning the body to Allah as clean as it was when gifted by Allah at birth. In that sense, one can never possess or own the body. Allah's ultimate sovereignty over both life and death is mediated through a claim on the body. Ensuring the return of the body to Allah as clean and pure as possible reflects the way in which it is held in trust by the deceased. This washing ritual also evidences the last respects that are paid to the deceased and the process of preparing the body for the afterlife.

The treatment of the dead body is intimately related to the formation of communal boundaries and forms of (un)belonging within communities (Balkan 2016). As explained earlier, the deceased's blood family members are the de facto agents of this bodily treatment, a designation that allows them to decide the deceased's sex and gender through washing and funeral practices. The strict display of a gender regime at Islamic funeral practices not only reaffirms the deceased's belonging in the family but also establishes the dead body's belonging in a given sex/gender category. The coffin design, the prayers at the mosque, the washing ritual prior to burial, and the rites of inhumation differ according to the state's determination of the sex of its citizens. For example, only officially trained ritual specialists and family members of the same sex as the deceased - the sex written on the ID_ can enter the special washing place, or gasilhane (see Figure 1), and practice the washing ritual. But it is also possible for the family to supersede the 
state definition of sex in the case of a transgender burial. During the ritual washing, the body is covered between the belly and the knees. The genitals should not be exposed while cleaning the body. The ritual washing is repeated three times. After the washing, cotton plugs are placed in the body openings. The body is then shrouded in a simple white cloth, or kefen, which symbolizes the equality of all before Allah. The face should not be exposed after shrouding.

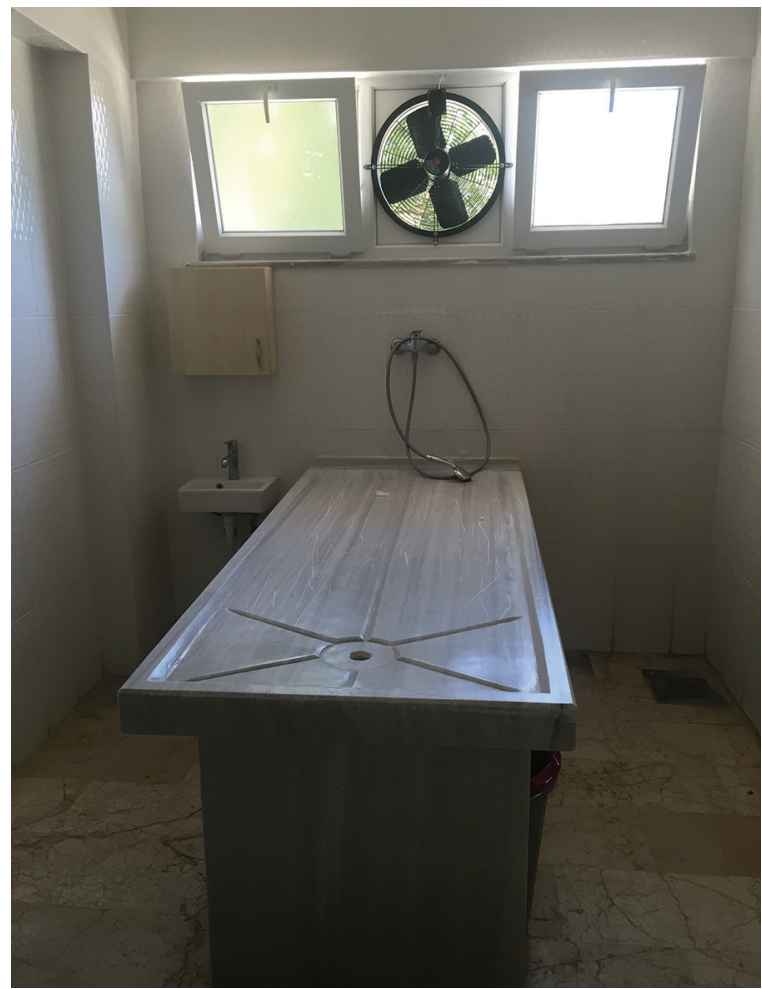

Figure 1. A gasilhane, or special washing place for the deceased. Photo by Aslı Zengin.

Kefen is made of three pieces of cloth for men and five pieces for women. The two additional pieces cover women's breasts and hair, parts that most observant Muslim women prefer also to cover in life, thus marking gendered/sexed difference. Prior to burial, the white-shrouded body is placed in a coffin covered with a green cloth upon which verses from the Qur'an about death are printed. If the deceased is a female, a headscarf is placed on the side of the coffin over the location of the head. A name tag, colored blue or pink depending on the gender of the deceased, is placed on one side of the coffin. Before the dead body is transferred from the mosque to the grave, male attendees of the funeral engage in prayers under the guidance of an imam, and they assemble around the coffin. In Turkey men usually 
perform the funeral prayer in the mosque, while women wait for its completion in the family home of the deceased. When women do attend funeral prayers at a mosque, they are required to stand at the back outside the mosque.

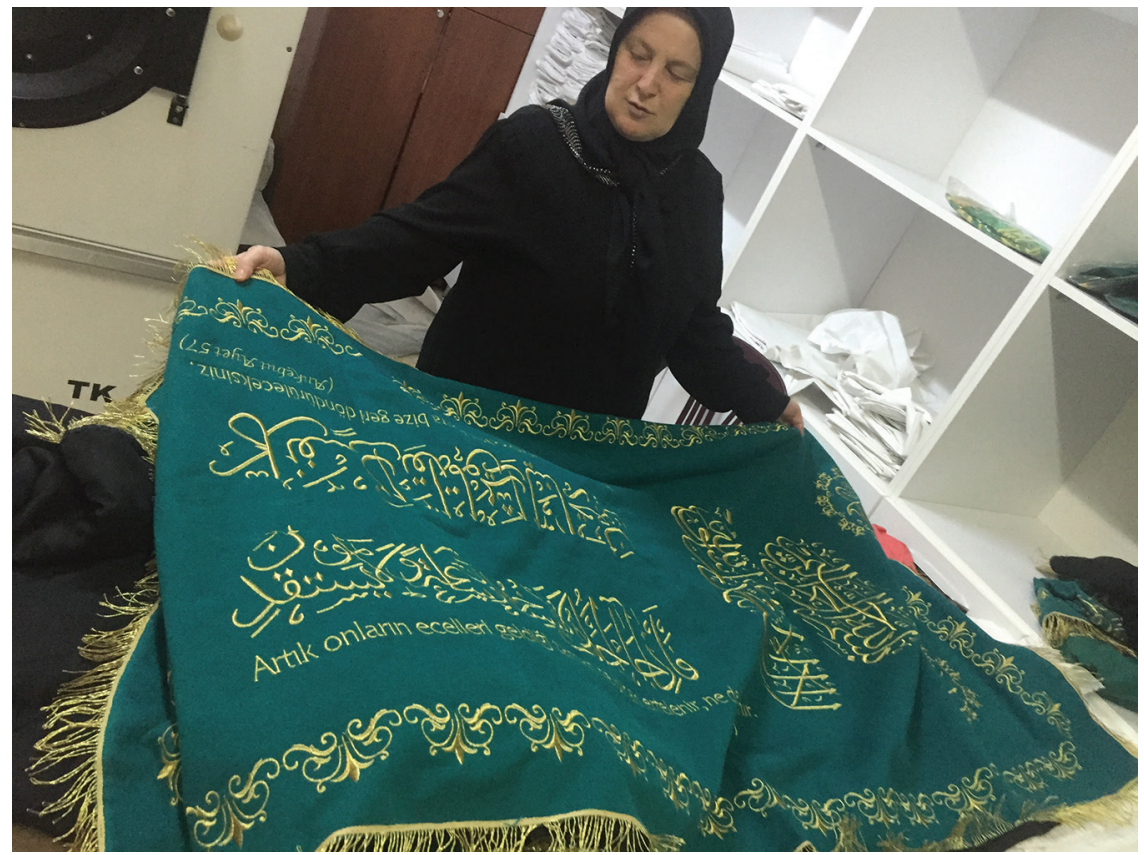

Figure 2. A green cover, on which verses about death from the Qur'an are printed. Photo by Aslı Zengin.

The imam's prayers - both in Turkish and Arabic - address the deceased as merhume or merhum and as hatun kişi or er kişi, gendered terms that announce the deceased as male or female. These gendered prayers are exceptional to the Turkish language, which is gender-neutral and has no distinct gender pronouns for women and men. On the contrary, all objects and human and nonhuman subjects have the same pronoun.

On the completion of prayers, the dead body is carried to the graveyard, taken out of the coffin by men, and buried in the white shroud. Only men may be present around the graveyard during the burial, regardless of the deceased's gender. Again, women are usually expected to either stand in the background or stay at home.

A popular Turkish saying, ölüm karşısında herkes eşittir, states that people are made equal in death. The official and actual organization of funeral and burial rituals, however, demonstrates that diversities in ethnicity, class, denomination, and gender and sexual identity may play a significant role in determining the pertinent funeral and burial practices, including the design of gravestones (see Eldem 2005; Sağır 
2013). The headstone design varies according to the material used, its size, and the personal information - even a picture in some instances - written on the stone.

Given the gender dichotomy embedded within Sunni Islamic funeral practices, it is no surprise that gender-nonconforming bodies, including Sibel's, might invoke questions. People who follow Sunni interpretations of Islam might view the sex/gender-trangressive body as a challenge to Islamic notions of embodiment, that is, to Allah's ascription of sex to each body. Imams may refuse to organize a ceremony for a deceased transgender person, they may refuse to conduct the prayers, or may consent to do so only if the prayers are gendered in the same way as the sex assigned at birth. ${ }^{5}$

Imams usually have recourse to and make use of state authorities and medico-legal regulations on sex and gender while they deliberate over the transgressive body. For example, the Directorate of Religious Affairs (Diyanet İşleri) dictates the organization of funeral rituals based on a reading of the material surface of the body - meaning that the funeral ceremonies of trans women who have not undergone gender reassignment surgery (GRS) are practiced in compliance with the sex assigned at their birth and marked on their state identification card. Although they lived as women, the funeral and burial rituals related to their bodies are expected to be performed by men. If they had GRS and had their IDs reissued to reflect their reassigned gender/sex, then state and religious authorities require women to perform the corpse washing, cleaning, and wrapping rituals. In short, the state and Sunni Islam, which derive their sovereignty from two different scripts - civil law and centuries of interpretation and argumentation of the Qur'an, hadith and sunnah respectively — work in alliance to reinscribe the gender/sex of the dead body.

The alliance between these sovereignties came into evidence at Sibel's funeral. Ceyda, a fifty-year-old trans woman and a close friend of Sibel, told me how it had been difficult to find a mosque willing to do the funeral and prayers for Sibel, since most of the imams rejected organizing a ceremony once they learned that the deceased was a trans woman. Some imams had even refused to do the funeral prayers and thus denied final religious rites to Sibel. A few imams had consented to perform the prayers and burial rites as long as she was referred to as a male. They recognized the blue ID, the state's inscription of sex, as Sibel's true sex, dismissing Sibel's life as a woman and her identity as such. Sibel's friends rejected this option and kept looking for an imam who would agree to conduct her funeral ceremonyto recognize, in death, that she had lived and died as a woman.

This effort points to fissures in the alliance between state and religious sovereignties. These fissures are produced by communal action - in this case, the actions 
of a community of trans women - and a growing body of Islamic jurisprudence on sex/gender nonconformity in various Muslim contexts that reads sex/gender embodiment as open to practice, negotiation, and interpretation (Najmabadi 2013; Ragab 2015; Almarri 2016; Hamzić 2016; Alipour 2017; Zainuddin and Mahdy 2017). Alongside ongoing debates and interpretations within Islamic traditions, people themselves seek their right to religious practice, and even their "right to sin" (Savcl 2016, 176). Families or the friends of the deceased may succeed in persuading religious authorities to perform funeral practices pertinent to the lived gender and sexual identity of the deceased.

Moreover, the dead trans body is not alone in causing a rupture in prescribed religious traditions relating to death. For example, Aslıhan Sanal (2011) discusses this issue in the context of organ donation in Turkey. Another example is committing suicide, one of the greatest sins in Islam, viewed as one greater than homicide. Since the body is an emanet, a borrowed thing from Allah, a human cannot violate its right to live. The practice and conferral of a traditional religious funeral ceremony and burial for a person who committed suicide thus also produces an ambiguous space for imams, a space within which to practice Islamic authority. Some imams refuse to organize a religious ceremony, while others may gain some flexibility by finding an excuse for the deceased's suicide. They may, for example, justify the conferral of a religious funeral ceremony for a suicide on the grounds of a momentary loss of sanity or short-lived hysteria. The dead bodies of hunsa, or intersex people, also produce ambiguities and modulations in death practices. Traditionally, neither women nor men practice the full washing ritual for intersex people. Instead, the washer wraps their hand with a piece of cloth and performs a cleaning ritual of the face and arms only, using purified sand or dust. While state-issued gender identity is seen as the principle criterion for performing the gendered practices of funeral ritual, in cases of an intersex person an imam might try to learn how the person identified in their lifetime. In case this information is impossible to acquire, the imam could act according to the testimonies of those who knew the deceased in life.

Mostly it is families and loved ones who locate and press sympathetic imams for the conferral of appropriate death rites for trans people, intersex people, and people who have committed suicide in Turkey. These spaces of religious ambiguity and interpretation allow individual imams to practice their authority. They also demonstrate alliances that form between members of vulnerable communities and imams. Sibel's friends, for example, eventually found an imam who agreed to practice her funeral and burial rituals according to Sibel's self-identified gender. 
At the funeral, I was nervous about how Sibel's gender would be addressed in the prayers. However, I did not need to wait for the imam's prayers: I saw the coffin, covered in a green cloth with a headscarf placed on the side where the person's head would rest. The imam of this mosque had recognized Sibel as a female, despite her having a state ID that still (mis)recognized her as male. He grounded his interpretation in his long-term residence in a neighborhood with a high population of transgender people and in his authority as an imam. His familiarity with transgender lives and communities led him to take a particular interpretive approach.

The imam concluded his gender-appropriate prayers for Sibel and asked for people's helal, blessings to the dead person and the last chance to forgive the deceased for misdeeds before the burial. When sending someone off to the graveyard (in Islam, a passage to the other world), it is rare for someone to deny their blessings to the deceased. Under the imam's guidance, we all gave our blessings to Sibel.

Sibel's funeral, however, also presented the problem of the corpse-washing ritual and the placement of her grave in the cemetery. Who would-and who should - organize the funeral rituals and material resources for the burial? As Ceyda, Sibel's close friends, and I walked toward the mosque's gate, we saw Sibel's mother sitting in a chair in front of the mosque, accepting people's condolences. Sibel's mother, her sister, and I were the only non-trans women at the funeral. In fact, along with Sibel's brother-in-law and the imam, we were the only non-trans people at the funeral. Sibel's mother and sister were present at the funeral, but they had chosen not to participate in the washing ritual - a particularly intimate familial obligation. They maintained a distance from Sibel's dead body through withholding this most intimate of death rites, as well as the affective, social, and kinship effects these rites are meant to produce. Instead of Sibel's blood family members, Ceyda had performed the ritual washing of Sibel's body. As we were leaving the mosque, Ceyda remarked on the many times she had had to wash, clean, and wrap the dead bodies of her trans friends, since so many blood families had completely abandoned their trans children and did not want to touch their bodies, even in death. ${ }^{6}$

The stigmatization of sex work also comes into play in the distance that blood families produce by not performing death-rite obligations. The majority of trans women in Turkey have difficulties finding jobs in sectors other than sex work, and the stigmatization of sex work and transphobia in tandem often lead to severed intimate relations with blood families over the course of trans people's lives. Despite this, throughout my research I did not come across a single story of a blood family denying burial and funeral rites to a cis woman sex worker, whereas stories of funeral denials to trans women were commonplace. 


\section{SOVEREIGNTIES OF INTIMACY: Love, Care, and the Real Family}

My fieldwork was punctuated by stories of two family forms that frequently had contrasting roles in transgender women's lives: blood families who abandoned their transgender kin in life and death, and the LGBTQ community and friends who stepped in, claimed, and protected transgender women in times of abandonment and violence, as well as in times of death. This intimate becoming, I suggested earlier, creates room for thinking about sovereignty from a different perspective that highlights its close associations with relations of care, bonds of intimacy, and the creation of affective communities in the face of everyday violence. More precisely, at transgender funerals we see the intimate work of care, love, protection, and claims that LGBTQ activists and friends of the deceased generate in the afterlife of a sex/gender-transgressive death. The LGBTQ community and friends often reclaim the body and organize the funeral, thereby taking the place of the blood family as the real family (see also Avramopoulou 2017; Çalışkan, forthcoming). LGBTQ lives, and in particular trans lives, are shaped by abandonment and disowning. As such, they consistently invest in their friendships and comradeships and contest the primacy given to blood families.

This is what happened at the mourning ritual following Sibel's burial, held at Istanbul LGBTT. When I entered Istanbul LGBTT, I saw about ten pairs of shoes lined up next to one another on the floor, ranging in color and in degree of wear. The shoes were now waiting to embrace new feet and carry new bodies, a practice that has become tradition in the trans community: when a trans woman from the community dies, friends collect objects and belongings from her house and exhibit them for people to take according to their needs and preferences. This redistribution of resources - an intimate gift economy of the dead - makes for yet another way in which a community of trans women proclaims itself a family.

Someone made helva, another ritual for the dead. Traditionally, ölü helvası (helva of the dead) is a dessert prepared with semolina or flour, sugar, and butter, and then cooked and served by the deceased person's family for the participants of the funeral following the interment. As people eat helva, they also talk about the departed and remember them. For Sibel's funeral ceremony, one of the trans women had taken on the role of cooking sufficient portions of helva and bringing it to the center. I had not seen the place so jam-packed before, but Sibel's blood family remained absent — as they had at the cemetery. They departed from the mosque immediately after Sibel's body did and returned home. Sibel's mother and sister had also asked Ceyda to tell other trans women not to come visit them in their homes to give their condolences. They would not welcome them inside the house. Sibel's 
burial plot was bought with money pooled by trans women; Sibel's blood family had contributed nothing. This was not the first time the community had pooled their resources for a deceased friend, nor would it be the last. When Ceyda saw that I was impressed, she turned to me and said: "When I die, they're gonna do the same thing. After all, we are each other's family! We are the real family!"

The emphasis on "real" family-making becomes most evident in violent moments of everyday life - when trans people face exclusion, displacement, and abandonment. It is both analogous and dissimilar to Kath Weston's (1991) work on "chosen families" among gay men and lesbians in the San Francisco Bay Area. Although Weston's chosen families form a sort of network in their interactions with one another across household lines, they still maintain affective attachments to and through the sense of a nuclear home, which becomes central to couples' relations and which other gays and lesbians might enter and exit as lovers, friends, and/or solidarity partners. Households on the model of a nuclear-family home are maintained as nodes, bases, or continuities within a larger network of queer kinship. In that sense, links between a sense of home, domestic household, and affective family retain their significance among Weston's queer families.

Yet in Istanbul, among the LGBTQ community in general and trans people in particular, I found less investment in maintaining nuclear structures of family-making in relation to the space of home than in making the family a form that brings many trans people together through LGBTQ organizations. That is why Sibel's shoes were displayed and her helva cooked and served at Istanbul LGBTT instead of at any other house. In other words, a network of trans people, emerging through political struggle and the spaces created by different LGBTQ organizations, comes to define itself as the queer family. As I have learned, many members of these organizations speak of organizing and community spaces as their home, as opposed to their individual dwellings, where they either live alone or with roommates or partners. Furthermore, when they write wills they often request to be buried by their queer families, not by their blood families.

Queer family- and kin-making more often concerns breaks and discontinuities than stabilities and continuities. Borrowing from David Eng's $(2010,15)$ discussion of "the feelings of kinship that threaten ... 'to disappear irretrievably' if we do not recognize and seize hold of them," I suggest that the LGBTQ community also develops a feeling of kinship that derives from a social archive of transgender deaths and shared experience of violence and threat of death. Dilara Calışkan (forthcoming) tackles this relationship between transgender deaths, memory, and temporality by examining how the LGBTQ community socializes this archive into 
practices of intimacy, including care, bonds, connections, protection, and division of labor at the moment and in the aftermath of death. I would like to push this insight further and to claim that, both in its material and affective documentation and in its archival collection of past, present, and future intimacies in the LGBTQ community, each deceased transgender body becomes a tangible and intangible temporary home - as well as a space for homemaking — for transgender people.

Returning to the scene of Sibel's funeral, I spent the entire day with Ceyda after the burial. She recounted another story, in which efforts to reclaim the deceased body of another trans friend, Ayşe, had failed, and the blood family did not let Ayşe's friends organize a funeral. This other family had disavowed their trans daughter both in her life and her death, and had requested that the state bury Ayşe in a cemetery for the unknown. Turning into a necroviolent actor, the family denied an afterlife to Ayşe, rendered her anonymous, and cast her body out from socially recognizable scripts of mourning.

Judith Butler (2004) has long drawn our attention to those unequal and differential economies of mourning that proclaim some deaths as grievable, while denying bereavement to others. One can describe the cemetery for the unknown as one of the chief architectures in this economy of mourning. In this graveyard the state buries the bodies of those who remain unidentified or unclaimed over a certain period of time. In practice, it constitutes a burial site for marginal people, namely, homeless people, victims of honor crimes, and more recently, unaccompanied Syrian refugees.

There is also a political dimension to these cemeteries for the unknown: they abound with the bodies of political detainees who were disappeared under police interrogations and state violence. Historically, the state has deemed many radical leftists and Kurdish guerrillas unidentified, denied families and communities these bodies, and buried them as anonymous corpses.

The three most popular cemeteries for the anonymous are located within the graveyards of Kilyos in Istabul, Sincan in Ankara, and Dogancay in Izmir. Cemeteries in other Turkish cities have also allocated specific sites to the burials of the unknown. These graves usually lie side by side, with a numbered plate assigned to each. Numerical representation functions as a technical tool either to manifest anonymity or to transform an already existing identification into an anonymous sign, especially in the case of supposedly terrorist bodies.

The cemeteries for the unknown attracted attention following the coup attempt against Recep Tayyip Erdoğan's government on July 15, 2016. In the aftermath, the Directorate of Religious Affairs released a statement denying funeral rights and burial practices to sixteen soldiers who had been part of the coup. Ten 
of these dead soldiers were not claimed by anyone, and their bodies remained in the morgue until their planned transport to the cemetery for the unknown. The mayor and municipality of Istanbul, however, constructed an entirely new cemetery, called Hainler Mezarlığı (the Cemetery for Traitors), for these soldiers. The mayor wanted to prevent these men from receiving prayers from people who might visit the cemetery and pray for the unknown. He publicly stated that people should curse and humiliate the graves of coup-affiliated soldiers, claiming that this new cemetery for traitors would constitute a perfect site for such acts. Eventually, the Directorate of Religious Affairs intervened and the municipality of Istanbul had to remove a sign above the newly constructed cemetery proclaiming it "The Cemetery for Traitors." However, the site continues to mark a mortal location for treason in the popular imagination.

The cemeteries for the unknown terrify Ceyda. Long removed from her blood family, she has already decided to donate her corpse as a cadaver for use in anatomy courses at medical schools, in part to avoid being buried as an "unknown." Sanal (2011) offers a detailed discussion of this arrangement between medical schools and the Council of Forensic Medicine. She explores how mentally ill people have been denied full personhood and rights over their own bodies since the early years of the Turkish republic, because they depended on others and did not have mental health. When they died, they were deemed homeless unless a relative claimed or the anatomy lab demanded them (Sanal 2011, 121). In that case, they were buried in the cemetery for the unknown. With the release of a circular by the Supreme Board of Judges and Prosecutors in October 2011, the Council of Forensic Medicine linked bodies that fall under the category of homeless to cadaver regulations even more stringently. According to this procedural change, the Council of Forensic Medicine has decided to deliver to medical schools those bodies not claimed by family members within fifteen days following death, placing these cases under the category of anonymous (Haberturk 2012). While people can request that their bodies be donated to medical schools upon death, the donor's family often feels reluctant to fulfill the donor's wish, a reluctance with which the state complies. Some medical schools have had to return corpses to families that insist on organizing a burial for the deceased.

Such moments further mark the body of the dead as a social body that has been (re)produced and shaped within the relations of kinship and family. The burial rituals represent not only the last obligations to the deceased but also a social obligation for the family to present itself as a family to society. Ceyda did not think anyone in her blood family would contest her decision to donate her body to sci- 
ence, precisely because she did not believe that anyone in her blood family would claim her body or organize a funeral.

While talking to her about her not-yet-dead body, I was struck by the way that Ceyda drew out the regulatory apparatus behind the making of the known or unknown cadaver: unless she donated her body to science, she explained, there would be a chance of her being regarded as anonymous. Furthermore, if she donated her body, there would be no legitimate actor who could contest her will and take back her body. Ceyda was afraid that the state might not recognize the yearslong relations that gelled into queer family-making between her and her trans friends. If the state did not recognize this relationship, it would claim the body as its own and decline to return the body to Ceyda's trans friends for a funeral.

Moreover, she was unsure whether her trans friends could mobilize enough people and capital to buy a grave plot in a regular cemetery for the known, because these were extremely expensive. Ceyda felt comforted by the idea of donating her body as a cadaver to medical students, explaining: "At least my body could contribute to something scientific." In this way Ceyda also proclaimed sovereignty over her future deceased body, over the afterlife of her transgender body. It was a claim shaped by her experiences living with the deaths of her trans family members, particularly that of Ayşe - whose blood family had insisted on burying her in a cemetery for the unknown even though her queer family had raised the funds and bought a burial plot for Ayşe in a cemetery for the known. The blood family had exercised its state-given right to Ayşe's dead body and refused the claims of Ayşe's queer family, although the latter, and not her blood family, had cared for Ayşe for years. Ceyda and the rest of Ayşe's queer family could do nothing.

In the absence of a will or a marriage, the blood family is the only actor to inherit the property the deceased has left behind. So trans women told stories about some blood families who did not hesitate to deny funeral rights to their trans children, but at the same time claimed their wealth. The family's refusal of the obligation of intimacy in Ayşe's case was not just an act that broke ties between the blood family and the trans child; by not allowing Ayşe a burial ceremony organized by her trans friends, they also sought to destroy trans intimacies, obligations, and relations. As Ayşe's funeral story demonstrates, the blood family, as it is recognized and constructed by the state, can kill a person beyond their physical death. The blood family can be one of the most violent sovereign models of intimacy - a deadly one, in fact.

The production of intimacy between family members is frequently coupled with strict rules of producing, ordering, and regulating lives, bodies, and desires. The family, with all its emotional, material, and symbolic work, includes and ex- 
cludes through drawing borders between different bodies and desires, inscribing its sovereignty over family members. Sara Ahmed (2006) astutely argues that to be a family member demands that one follow the family line, that is, the naturalization of heterosexuality as a line that directs bodies to desire the body of the opposite sex. Inheritance of this family line also constitutes the condition of family love. Hence, when a child fails to inherit a desire and orientation for a hetero-reproductive future, she/he risks the material, social, and affective capital provided by the family (see also Weston 1991). Among these conditions is not only sexual orientation but also gender identity (see Yanagisako and Collier 1987). In other words, many families require their children to inherit and integrate not only heterosexual desire but also cisgenderism into the construction of their selves so as to be recognized as those families' respectful, loved, and cared-for members.

The state's sustenance of a dominant intimate order in Turkey strictly depends on the circulation and cultivation of desires for and within hetero-reproductive family life, which has become increasingly prominent in emerging forms of governance, particularly under the current AKP (Justice and Development Party) government (see Kocamaner 2014). This family model is the only legally recognized organization of intimacy in Turkey, and it forecloses alternative ties of relatedness (remember, here, the IVF regulations restricted to heterosexual couples) — a situation also found in many other countries (Mikdashi 2018). Trans people's sovereign claims over their intimate relations with their friends and their bodies are contested, negotiated, and shaped at the intersection of those legal regulations, institutional practices, and norms that inscribe the hetero-reproductive nuclear family as the hegemonic model of intimacy in Turkey.

Sibel's funeral demonstrates how her trans friends' claims on her deceased body became mediated through the heteronormative family, the state, and Islam. In Ayşe's case, however, her friends' claims on her body were denied due to the state's legal inscription of blood-family sovereignty over the dead body as it relates to funeral rites. It is crucial that scholars pay more attention to the role of the state as the mediator and authorizer of particular forms of intimacies between trans people, their blood families, and other social actors, as well as of the limits on the sovereignty that trans people claim over their intimate bonds and definitions of sex and gender.

\section{CONCLUSION}

This article has argued that the entanglements between religious interpretation, familial order, and gender and sexuality regimes, as well as the secular laws 
governing the individual body in Turkey, embed close relationships between sovereignty and intimacy, which become apparent through emergent collective struggles over transgressive deaths. Death at the threshold of dominant regimes is never an ending, but rather an initiation into intimate and violent afterlives. In these afterlives, I have suggested that the LGBTQ community and friends of the deceased produce localized and provisional forms of sovereignty through practices of care and love toward a sex/gender-transgressive death. Transgender women deploy the family as a sovereign form of intimacy but strategically rework it through queer alignments. They contest intimate sovereign alliances between the state, Islam, and blood family, and thus survive their disowning and abandonment. In this way, they “secure 'space' for death and mourning" (Avramopoulou 2017, 75) and register it as a loss into the heart of life.

Death and its afterlives become vital to how trans people relate to one another and to society at large - including its relationship with religious authoritiesthrough the creative work of living. Trans people turn death itself into ways of becoming political and intimate subjects, remaking the conditions of their living (see Zengin 2016a). The contestations over who provides meaning to ritual constitute a struggle over futures for trans/queer social worlds. The queer family intervenes in and ruptures the ritual domain of religious and cultural practice, transgressing multiple sovereign arrangements of sexuality, sex, gender, kinship, and citizenship. Caring for the dead, in these political and social projects, becomes an emergent form of sovereignty that invigorates life in an intimate way.

Like any other death, transgender deaths are social events, a contentious symbolic and material field in and through which social order in Turkey or elsewhere is formed, negotiated, and contested. Transgender deaths provide just one example among many other transgressive deaths that constitute a field of social contestation for interrogating how heterogeneous and mostly antagonistic understandings of sex, gender, ethnicity, citizenship, and religion meet and entangle with each other, and how they shape and define both life and death in the margins. Each of the stories presented here - from Sibel, Ayşe, Cemile, and Ekin Wan to unclaimed refugees, suicides, homeless people, and so-called terrorists - demonstrates that death marks the ethnic, sexual, gendered, and economic limits of belonging in regimes of family, kinship, religion, and citizenship, as well as in practices of mourning and grief. Multiple forms of transgression open the organization of social difference to debates and negotiations by various actors who, in turn, advance diverse claims on the body of the deceased, sovereign intimacies that coexist in concert or collide with each other. 
Violence, death, and intimacy at the limits of gender and sexuality regimes are not a phenomenon unique to Turkey. We live among the ghosts of gender-nonconforming deaths in a multitude of temporal and spatial registers. To name a few: those Indigenous Two Spirit people massacred at the hands of European colonial gender regimes; those so-called hermaphrodites staged as scientific objects of inquiry for the European medico-legal gaze; those who died in the United States under the Reagan government during the HIV/AIDS crisis of the 1980s; black trans people and trans people of color who are targeted for hate crimes and who die (and live) in Euro-American countries every day. We have many deaths to remember, mourn, and commemorate. May these stories from Turkey help you remember and grieve some of your own ghosts.

\section{ABSTRACT}

Family and sexual / gender difference play significant roles in the organization of Sunni Muslim rituals of death, practices of mourning, and discourses of grief in Turkey. In these ritual practices, family members hold obligations and rights to the deceased, including washing, shrouding, burying, and praying for the body. These funeral practices represent the dead body in strictly gendered ways. However, when the deceased is a transgender person, his/her/their body can open a social field for negotiation and contestation of sexual and gender difference among religious, medico-legal, familial, and LGBTQ actors. Addressing the multiplicity of such struggles and claims over the deceased body of transgender persons, this article presents a mortuary ethnography that is formed through entanglements between Islamic notions of embodiment, familial order, gender and sexuality regimes, and legal regulations around death in Turkey. Rather than taking sex, gender, and sexual difference as given categories, I address them as a social field of constant and emergent contestation, which in turn marks the gendered and sexual limits of belonging in regimes of belief, family, kinship, and citizenship, and in practices of mourning and grief. I argue that death at the thresholds of sexual and gender regimes presents a space to discover novel connections between sovereignty and intimacy and to examine their coconstitution through the registers of violence endured by the gendered/sexed body. [sovereignty; intimacy; transgender; death; Islam; Turkey]

\section{ÖZET}

Aile ve (toplumsal) cinsiyet farklılı̆̆ Türkiye’deki Sünni Müslüman cenaze gelenek ve adetlerinde, yas tutma pratiklerinde ve acı söylemlerinde önemli rol oynar. Cenazeyi yıkamak, kefenlemek, toprağa vermek ve cenaze için dua etmek gibi pratikler ailenin ölen mensubuna karşı sahip olduğu sorumluluk ve haklardan bazılarıdır. Bu pratikler ölen kişiyi katı bir cinsiyet ikiliği içerisinde temsil eder. Fakat ölen kişi bir trans birey ise, ölü bedenin cinsiyeti din, tıp, hukuk, aile ve LGBTQ çevreleri arasında çatışma ve 
müzakere alanına dönüşebilmektedir. Bu makale ölü trans bedenlerin açtığı bu çoklu hak ve mücadele alanına değinerek, Türkiye’deki İslami beden tasavvuru, aile düzeni, cinsellik ve toplumsal cinsiyet nizamı ve ölümle ilgili hukuki düzenlenmeler sarmalında oluşan bir ölüm etnografisi sunmaktadır. Toplumsal cinsiyet ve cinsellik kategorilerini sorgusuz sualsiz kabul etmek yerine, onların sürekli müzakereye tabi olan ve yeni müzakerelere yol açan toplumsal bir alan olduğunu ve böylece kişilerin din, aile, akrabalık ve vatandaşlık iliş̧ileri, yas ve acı pratikleri içerisindeki aidiyetliklerinin sınırlarını devamlı çizdiklerini tartışıyorum. Cinsellik ve (toplumsal) cinsiyet düzeninin çeperlerinde gerçekleşen ölümün egemenlik ve mahremiyet/yakınlık arasında kurulan ilişkiyi bizlere yeni şekillerde görme imkanı açtı̆̆ını ve şiddetin cinsiyetlendirilmiş beden üzerindeki kaydına bakarak ikisinin birbirini karşılıklı olarak nasıl kurduğunu anlayacağımızı iddia ediyorum. [egemenlik; yakınlı;; mahremyiet; transgender; ölüm; İslam; Türkiye]

\section{NOTES}

Acknowledgments This article benefited from the generous intellectual environment provided by the Women's Studies in Religion Program at Harvard Divinity School during my tenure in 2017-2018. Thanks to colleagues at the University of California, Berkeley, the University of Cambridge, Columbia University, Harvard University, Brown University, Washington University in St. Louis, the College of William and Mary, Boston University, and Amherst College for inviting me to share my work and providing me with insightful feedback. I am extremely grateful to Amahl Bishara, Kimberley Blockett, Ann Braude, Jean Comaroff, Avital Davidovich Eshed, Gökçe Günel, Ferial Khalifa, Maya Mikdashi, Durba Mitra, Afsaneh Najmabadi, Laura Prieto, Nazan Üstündağ, and Emrah Yıldız for their invaluable comments on different versions of this article. Thanks also go to Thomas Abowd, Seçil Dağtaş, Mark Jordan, George Paul Mieu, Minoo Moallem, Gül Özyeğin, Sahar Sadjadi, Sertaç Sehlikoğlu, Vivian Solana, and Bettina Stoetzer, who attentively listened to my work and shared their insights. Finally, I appreciate the thoughtful engagement by four anonymous reviewers and the Cultural Anthropology editorial team, especially Heather Paxson, which greatly improved this article.

1. Despite its various interpretations, a headscarf is a dominant religious practice among Muslim women at a funeral ceremony. Even women who do not wear headscarves in their everyday lives usually attend funerals with their headscarves.

2. With the legislation of a new ID bill in 2016, civil registry offices have started to replace blue/pink IDs with smart white ones since January 2017. The new IDs now have digitized personal finger, vein, and palm prints, and will be issued until 2020. They still display dichotomous gender categories, but in verbal form. Time will tell whether this shift will create new possibilities for challenging gender binarism in institutional life.

3. For a detailed account on this medico-legal process, see Zengin 2014.

4. I use the term transgressive death not to denote death itself as transgressive, but to capture those social forms of transgression that emerge at the moment and in the aftermath of death in the margins of the social.

5. There have been other instances of funeral denials by Sunni imams when it came to the death rituals of Alevis (Zirh 2012) and supposed terrorists (Özsoy 2010).

6. Some trans women do succeed in maintaining relations with their blood family, although mainly through monetary transactions. The majority of the trans women I met during my fieldwork, however, had severed connections to their blood families. I should also note that such stories of abandonment extend beyond the boundaries of Turkey, reaching multiple geographies of racial, ethnic, religious, and gender difference. One can, for example, find powerful resemblances with those queer and transgender lives and deaths whose protag- 
onists were disowned by their families during the 1980s HIV/AIDS crisis in the United States.

\section{REFERENCES}

Ahmed, Sara

2006 Queer Phenomenology: Orientations, Objects, Others. Durham, N.C.: Duke University Press.

Alipour, Mehrdad

2017 "Transgender Identity, The Sex-Reassignment Surgery Fatwās, and Islamic Theology of a Third Gender." Religion and Gender 7, no. 2: 164-79. https://doi.

Almarri, Saqer A. org/10.18352/rg.10170.

2016 “'You have made her a man among men': Translating the Khuntha's Anatomy in Fatimid Jurisprudence." Transgender Studies Quarterly 3, nos. 3-4: 578-86. https:// doi.org/10.1215/23289252-3545251.

Avramopoulou, Eirini

2017 "Claims of Existence between Biopolitics and Thanatopolitics." In De/Constituting Wholes: Towards PartialityWithout Parts, edited by Manuele Gragnolati and Christoph Balkan, Osman F. E. Holzhey, 67-84. Vienna and Berlin:Turia + Kant/Verlag.

2016 "Charlie Hebdo and the Politics of Mourning." Contemporary French Civilization 41, no. 2: 253-71. https://doi.org/10.3828/cfc.2016.13.

Bargu, Banu

2016 "Another Necropolitics." Theory and Event 19, no. 1 (Supplement). http:/ / muse.jhu. edu/article/610222.

Berlant, Lauren

2007 "Slow Death (Sovereignty, Obesity, Lateral Agency).” Critical Inquiry 33, no. 4: 754 80. https://doi.org/10.1086/521568.

Bishara, Amahl

2017 "Sovereignty and Popular Sovereignty for Palestinians and Beyond." Cultural

Butler, Judith Anthropology 32, no. 3: 349-58. https://doi.org/10.14506/ca32.3.04.

2004 Precarious Life:The Powers of Mourning andViolence. New York: Verso.

Calıșkan, Dilara

Forthcoming "'Nobody is going to let you attend your own funeral': A Funeral for a Trans Woman and Naming the Unnamed." In Women Mobilizing Memory, edited by Ayşe Gül Altınay, María José Contreras, Marianne Hirsch, Jean Howard, Banu Karaca, and Alisa Solomon. New York: Columbia University Press.

Comaroff, John L., and Jean Comaroff

2009 "Reflections on the Anthropology of Law, Governance, and Sovereignty." In Rules of Law and Laws of Ruling: On the Governance of Law, edited by Franz von BendaBeckmann, Keebet von Benda-Beckmann, and Julia Eckert, 31-59. Burlington, Vt.: Ashgate.

Dean, Mitchell

2001 “Demonic Societies': Liberalism, Biopolitics, and Sovereignty." In States of Imagination: Ethnographic Explorations of the Postcolonial State, edited by Thomas Blom Hansen and Finn Stepputat, 41-64. Durham, N.C.: Duke University Press.

De León, Jason

2015 The Land of Open Graves: Living and Dying on the Migrant Trail. Oakland: University of California Press.

Edelman, Elijah Adiv

2014 “'Walking while transgender': Necropolitical Regulations of Trans Feminine Bodies of Color in the U.S. Nation's Capital." In Queer Necropolitics, edited by Jin Haritaworn, Adi Kuntsman, and Silvia Posocco, 172-90. New York: Routledge. 
Eldem, Edhem

2005 Death in Istanbul: Death and Its Rituals in Ottoman-Islamic Culture. Istanbul: Ottoman Bank Archives and Research Center.

Eng, David L.

2010 The Feeling of Kinship: Queer Liberalism and the Racialization of Intimacy. Durham, N.C.: Duke University Press.

Haberturk

2012 "Kadavra dağıtımı başlıyor." Health, March 30. http://www.haberturk.com/ Hamzić, Vanja saglik/haber/729564-kadavra-dagitimi-basliyor.

2016 "The Resistance from an Alterspace: Pakistani and Indonesian Muslims beyond the Dominant Sexual and Gender Norms." In Religion, Gender, and Sexuality in Everyday Life, edited by Peter Nynäs and Andrew Kam-Tuck Yip, 17-35. Burlington, Vt.: Ashgate.

Hansen, Thomas Blom, and Finn Stepputat

2006 “Sovereignty Revisited." Annual Review of Anthropology 35: 295-315. https://doi. org/10.1146/annurev.anthro.35.081705.123317.

Haritaworn, Jin, Adi Kuntsman, and Silvia Posocco

2014 "Introduction." In Queer Necropolitics, edited by Jin Haritaworn, Adi Kuntsman, and Silvia Posocco, 1-27. New York: Routledge.

Humphrey, Caroline

2004 "Sovereignty." In A Companion to the Anthropology of Politics, edited by David Nugent and Joan Vincent, 418-36. Malden, Mass.: Blackwell.

Kamer, Hatice

2015 "Cemile Çağırga'nın annesi: 'O gece kızımın cesedini koynuma alarak uyudum.” BBC News, Türkçe, September 15. https://www.bbc.com/turkce/ haberler/2015/09/150913_cizre_cemileninolumu_hatice_kamer.

Kocamaner, Hikmet

2014 "The Politics of the Family: Religious Affairs, Civil Society, and Islamic Media in Turkey." PhD dissertation, University of Arizona.

Mbembe, Achille

2003 "Necropolitics." Translated by Libby Meintjes. Public Culture 15, no. 1: 11-40. https://doi.org/10.1215/08992363-15-1-11.

Mikdashi, Maya

2018 "Sextarianism: Notes on Studying the Lebanese State." In The Oxford Handbook of Contemporary Middle Eastern and North African History, edited by Amal Ghazal and Jens Hanssen. New York: Oxford University Press. https://doi.org/10.1093/ oxfordhb/9780199672530.013.24.

Najmabadi, Afsaneh

2013 Professing Selves: Transsexuality and Same-Sex Desire in Contemporary Iran. Durham, N.C.: Duke University Press.

Navaro-Yashin, Yael

2012 The Make-Believe Space: Affective Geography in a Postwar Polity. Durham, N.C.: Duke University Press.

Özel, Çă̆lar

2002 "Medeni hukuk açısından ölüm anının belirlenmesi ve ceset üzerindeki hakka ilişkin bazı düŞünceler.” Ankara Üniversitesi Hukuk Fakültesi dergisi 51, no. 1: 43-77.

Özsoy, Hişyar

2010 "Between Gift and Taboo: Death and the Negotiation of National Identity and Sovereignty in the Kurdish Conflict in Turkey." PhD dissertation, University of Texas at Austin. http:/ / hdl.handle.net/2152/ETD-UT-2010-05-854.

Ragab, Ahmed

2015 "One, Two, or Many Sexes: Sex Differentiation in Medieval Islamicate Medical Thought." Journal of the History of Sexuality 24, no. 3: 428-54. http://muse.jhu. edu/article/592034. 
Sağır, Adem

2013 "Bir ölüm sosyolojisi denemesi bağlamında iktisadi hayata mezarlıklardan bakmak: Safranbolu örneği.” Turkish Studies 8, no. 12:1095-1115. https://doi.org/10.7827/ Sanal, Aslıhan TurkishStudies.5681.

2011 New Organs Within Us: Transplants and the Moral Economy. Durham, N.C.: Duke University Press.

Savcl, Evren

2016 "Subjects of Rights and Subjects of Cruelty: The Production of an Islamic Backlash against Homosexuality in Turkey." In Perverse Politics? Feminism, Anti-Imperialism, Multiplicity, edited by Ann Shola Orloff, Raka Ray, and Evren Savci, 159-86. Somerville, Mass.: Emerald.

Shakhsari, Sima

2014 "The Queer Time of Death: Temporality, Geopolitics, and Refugee Rights." Sexualities 17, no. 8: 998-1015. https://doi.org/10.1177/1363460714552261.

Simpson, Audra

2014 Mohawk Interruptus: Political Life Across the Borders of Settler States. Durham, N.C.: Duke University Press.

Söylemez, Ayça

2016 “Taybet İnan'ın oğlu, annesini defnedebilmek için anayasa Mahkemesine Başvurdu." Bianet, January 6. https://m.bianet.org/bianet/insan-haklari/170842-taybetÜstündă̆, Nazan inan-in-oglu-annesini-defnedebilmek-icin-anayasa-mahkemesine-basvurdu.

2015 "Ekin Wan bedeninde ifşa olan devlet ya da kadınlar sıra bizde [The state exposed in the body of Ekin Wan, or, women, it's now our turn]." Evrensel, August 23. http:// www.evrensel.net/haber/258899/ekin-wanin-bedeninde-ifsa-olan-devlet-ya-dakadinlar-sira-bizde.

Weston, Kath

1991 Families We Choose: Lesbians, Gays, Kinship. New York: Columbia University Press. Yanagisako, Sylvia J., and Jane F. Collier

1987 "Toward a Unified Analysis of Gender and Kinship." In Gender and Kinship: Essays Toward a Unified Analysis, edited by Jane F. Collier and Sylvia J. Yanagisako, 14-51. Stanford, Calif.: Stanford University Press.

Zainuddin, Ani Amelia, and Zaleha Abdullah Mahdy

2017 "The Islamic Perspectives of Gender-Related Issues in the Management of Patients with Disorders of Sex Development." Archives of Sexual Behavior 46, no. 2: 353-60. https://doi.org/10.1007/s10508-016-0754-y.

Zengin, Aslı

2014 "Sex for Law, Sex for Therapy: Pre-Sex Reassignment Surgical Therapy Sessions of Trans People in Istanbul.” Anthropologica 56, no. 1:55-68. https:/ /www.jstor.org/ stable/24469641.

2015 "Cemile Cagirga: A Girl is Freezing Under State Fire." Jadaliyya, September 17. http://www.jadaliyya.com/Details/32470/Cemile-Cagirga-A-Girl-is-FreezingUnder-State-Fire.

2016a "Mortal Life of Trans/Feminism: Notes on 'Gender Killings' in Turkey." Transgender Studies Quarterly 3, nos. 1-2: 266-71. https://doi.org/10.1215/232892523334487.

2016b "Violent Intimacies: Tactile State Power, Sex/Gender Transgression, and the Politics of Touch in Contemporary Turkey." Journal of Middle EastWomen's Studies 12,

Zirh, Besim Can no. 2: 225-45. https://doi.org/10.1215/15525864-3507650.

2012 "Following the Dead beyond the 'Nation': A Map for Transnational Alevi Funerary Routes from Europe to Turkey." Ethnic and Racial Studies 35, no. 10: 1758-74. https://doi.org/10.1080/01419870.2012.659274. 